\title{
Competing sexual and asexual generic names in Pucciniomycotina and Ustilaginomycotina (Basidiomycota) and recommendations for use
} \author{
Marvanová ${ }^{6}$, Yoshitaka Ono ${ }^{7}$, Mahajabeen Padamsee ${ }^{8}$, Markus Scholler ${ }^{9}$, Marco Thines ${ }^{10}$, and Amy Y. Rossman ${ }^{11}$ \\ edu \\ ${ }^{2}$ Mycology \& Nematology Genetic Diversity and Biology Laboratory, USDA-ARS, Beltsville, MD 20705, USA \\ ${ }^{3}$ Ruhr-Universität Bochum, Geobotanik, ND 03/174, D-44801 Bochum, Germany \\ ${ }^{4}$ ETH Zürich, Plant Ecological Genetics, Universitätstrasse 16, 8092 Zürich, Switzerland \\ ${ }^{5}$ Department of Biomedical Sciences and Engineering, National Central University, 320 Taoyuan City, Taiwan \\ ${ }^{6}$ Czech Collection of Microoorganisms, Faculty of Science, Masaryk University, 62500 Brno, Czech Republic \\ ${ }^{7}$ Faculty of Education, Ibaraki University, Mito, Ibaraki 310-8512, Japan \\ ${ }^{8}$ Systematics Team, Manaaki Whenua Landcare Research, Auckland 1072, New Zealand \\ ${ }^{9}$ Staatliches Museum f. Naturkunde Karlsruhe, Erbprinzenstr. 13, D-76133 Karlsruhe, Germany \\ ${ }^{10}$ Senckenberg Gesellschaft für Naturforschung, Frankfurt (Main), Germany \\ ${ }^{11}$ Department of Botany \& Plant Pathology, Oregon State University, Corvallis, OR 97333, USA
}

M. Catherine Aime ${ }^{1}$, Lisa A. Castlebury², Mehrdad Abbasi ${ }^{1}$, Dominik Begerow ${ }^{3}$, Reinhard Berndt ${ }^{4}$, Roland Kirschner ${ }^{5}$, Ludmila

${ }^{1}$ Purdue University, Department of Botany and Plant Pathology, West Lafayette, IN 47901, USA; corresponding author e-mail: maime@purdue.

\begin{abstract}
With the change to one scientific name for pleomorphic fungi, generic names typified by sexual and asexual morphs have been evaluated to recommend which name to use when two names represent the same genus and thus compete for use. In this paper, generic names in Pucciniomycotina and Ustilaginomycotina are evaluated based on their type species to determine which names are synonyms. Twenty-one sets of sexually and asexually typified names in Pucciniomycotina and eight sets in Ustilaginomycotina were determined to be congeneric and compete for use. Recommendations are made as to which generic name to use. In most cases the principle of priority is followed. However, eight generic names in the Pucciniomycotina, and none in Ustilaginomycotina, are recommended for protection: Classicula over Naiadella, Gymnosporangium over Roestelia, Helicobasidium over Thanatophytum and Tuberculina, Melampsorella over Peridermium, Milesina over Milesia, Phragmidium over Aregma, Sporobolomyces over Blastoderma and Rhodomyces, and Uromyces over Uredo. In addition, eight new combinations are made: Blastospora juruensis, B. subneurophyla, Cronartium bethelii, C. kurilense, C. sahoanum, C. yamabense, Milesina polypodii, and Prospodium crusculum combs. nov.
\end{abstract}

Article info: Submitted: 16 March 2018; Accepted: 26 March 2018; Published: 26 April 2018.

\section{INTRODUCTION}

With the change to one scientific name for all Fungi in accordance with the International Code of Nomenclature for algae, fungi, and plants (ICN, McNeill et al. 2012), it has been necessary to determine which generic name should be applied when two or more generic names are typified by different morphs of the same genus. Recommendations about which generic name to use have been made primarily by specialized Subcommissions or Working Groups of the International Commission for the Taxonomy of Fungi (ICTF), each representing a different group of Fungi. A number of papers recommending generic names for use have been published including the major groups of Sordariomycetes such as Diaporthales (Rossman et al. 2015a), Hypocreales (Rossman et al. 2013, Quandt et al. 2014, Kepler et al. 2017), Magnaporthales (Zhang et al. 2016), Microascales and
Key words: Basidiomycetes pleomorphic fungi taxonomy protected names rejected names unit nomenclature new taxa

๑) 2018 International Mycological Association

You are free to share - to copy, distribute and transmit the work, under the following conditions:

Attribution: You must attribute the work in the manner specified by the author or lice

$\begin{array}{ll}\text { Attribution: } & \text { You must attribute the work in the manner specified by } \\ \text { Non-commercial: } & \text { You may not use this work for commercial purposes. }\end{array}$

No derivative works: You may not alter, transform, or build upon this work.

For any reuse or distribution, you must make clear to others the license terms of this work, which can be found at http://creativecommons.org/licenses/by-nc-nd/3.0/legalcode. Any of the above conditions can be waived if you get permission from the copyright holder. Nothing in this license impairs or restricts the author's moral rights.

Ophiostomatales (de Beer et al. 2013), Xylariaceae (Stadler et al. 2013) and remaining Sordariomycetes (Réblová et al. 2016) as well as Dothideomycetes (Rossman et al. 2015b), Eurotiales (Samson et al. 2014, Visagie et al. 2014), Leotiomycetes including Erysiphales (Braun 2013, Johnston et al. 2014), Orbiliomycetes (Baral et al. 2017), Pezizomycetes (Healy et al 2016), yeasts (Daniel et al. 2014) and overlooked generic names in the Ascomycota (Rossman et al. 2016). A companion paper to this one on the Agaricomycotina is in progress. Generic names that follow the principle of priority whether they are sexually or asexually typified do not need to be confirmed by the Nomenclature Committee for Fungi (NCF) and General Committee of the International Botanical Congress (IBC). The former Art. 57.2 which required approve for the use of asexually typified names over sexually typified ones was removed from the Code at the 2017 International Botanical Congress (Turland et al. 2017, 2018). However, 
those generic names that do not have priority must be approved by the NCF.

Generic names of Pucciniomycotina and Ustilaginomycotina (Basidiomycota), representing sexually and asexually typified genera that compete for use have been evaluated by the Heterobasidiomycetes Working Group and the International Subcommission on Rust Taxonomy of the ICTF. Members of these groups have been consulted and agree with the recommendations made herein about which generic name to use 1 . The comprehensive list of sexual-asexual generic names by Wijayawardene et al. (2012) was used as the initial starting point for discovering competing basidiomycete generic names. Citations for generic names and type species are based on Index Fungorum. Each set of generic names was evaluated based on the phylogenetic placement of their type species using the literature to determine whether the names are congeneric. Then a recommendation for use is made considering such factors as priority, number of species and thus number of required name changes, use outside of the ICN, frequency of citations in the literature and frequency of use based primarily on number of citations in Google Scholar (GS).

Here we advocate abandoning the use of many asexually typified generic names in Pucciniales such as Aecidium, Caeoma, Milesia, Peridermium, Roestelia, and Uredo for their corresponding sexually typified generic names. This is problematic as many species have been described using these names. Often it is difficult to determine in which genus a rust fungus belongs because of the lack of the telial stage. However, these formal asexually typified generic names are based on type species that are synonyms of species in other genera. In the case of Aecidium and Caeoma these generic names are synonyms of an earlier generic name, Puccinia. For Peridermium the type species is a synonym of a species in Melamsporella, a later generic name that is recommended for protection over Peridermium; most species described in Peridermium, however, belong in Cronartium. Similarly, the type species of the generic name Roestelia is a synonym of the type species in Gymnosporangium, an important and well-defined genus that is recommended for protection. Finally, the generic name Uredo is a synonym of the later name Uromyces, which is recommended for use for two reasons. Firstly, species of Uredo belong to many different rust genera, and secondly Uromyces is a commonly used generic name. See under those generic names for more detailed discussion.

Although the abandoned Pucciniales asexual morph names should no longer be used to describe new species, the species already described in those names are not invalidated and can still be used. As for all scientific names

${ }^{1}$ Heterobasidiomycetes Working Group: Dominik Bergerow, Convenor; Cathie Aime, Stephan Helfer, David McLaughlin, Hai Nguyen, Maj Padamsee, Angela Schäfer, Qi-Ming Wang, and Andrey Yurkov.

International Subcomission on Rust Taxonomy: Cathie Aime, Chair; Mehrdad Abbasi, Gaddam Bagyanarayana, Reinhard Berndt, Cvetomir Denchev, José Dianese, Richard Hamelin, Stephan Helfer, Drew Minnis, Yoshitaka Ono, and Markus Scholler. that cannot be correctly placed in a genus, the problem with the generic name could be noted by including quotes around the name or by indicating the temporary taxonomic placement with "pro tem." as has been suggested for anamorphically typified species of Ustilaginomycotina (Wang et al. 2015b). Efforts will be made in the future to determine the correct generic placement for the names currently in use in these asexually typified genera. With the increasingly available use of molecular data for determining phylogenetic relationships, the need for these asexually typified names of rust fungi should be eliminated or, as has been done for years, species known only from an asexual state can be placed in the genus most likely to be considered correct.

Generic names used for asexual rust fungi can, however, be used in a non-latinized sense to describe a morphology, as illustrated in Cummins \& Hiratsuka (2003). As in other groups of fungi, for example, a species may be described as having ascomata that are nectria-like, meaning they produce light- to bright-coloured, fleshy perithecia, or fusarium-like meaning that they produce fusiform, multiseptate, hyaline conidia. Thus, one can refer to an asexual morph of a rust fungus as being aecidium-like, caeoma-like, peridermiumlike, or uredo-like.

Twenty-one sets of sexual and asexual generic names in Pucciniomycotina and eight sets of generic names in Ustilaginomycotina were determined to compete for use and evaluated for recommended use. Most of the generic names recommended for use have priority. None of the names of Ustilaginomycotina but eight generic names of Pucciniomycotina do not have priority and are recommended for protection over older names, specifically: Classicula over Naiadella, Gymnosporangium over Roestelia, Helicobasidium over Thanatophytum and Tuberculina, Melampsorella over Peridermium, Milesina over Milesia, Phragmidium over Aregma, Sporobolomyces over Rhodomyces and Blastoderma, and Uromyces over Uredo. Details about each set of generic names and the basis for each decision are presented below with an $S$ indicating a sexually typified name and an $A$ indicating an asexually typified name. The citation for each generic name, type species, accepted name of type species, and action required are listed in Table 1 for Pucciniomycotina and Table 2 for Ustilaginomycotina.

\section{COMPETING SEXUAL AND ASEXUAL GENERIC NAMES OF PUCCINIOMYCOTINA, BASIDIOMYCOTA AND RECOMMENDATIONS FOR USE}

\section{Use Basidiopycnis Oberw. et al. 2006 (S) rather than Basidiopycnides J. Reid et al. 2008 (A)}

The monotypic generic name Basidiopycnis is typified by the sexual species $B$. hyalina, described from bark beetle galleries (Oberwinkler et al. 2006). Another monotypic generic name Basidiopycnides typified by $B$. albertensis was described for an asexual morph also from bark beetle galleries (Hausner et al. 2008). Kirschner \& Oberwinkler (2009) confirmed the relationship between these types as sexual and asexual morphs of the same species and 
Table 1. Recommended generic names of Pucciniomycotina among sexual-asexual names that compete for use. The recommended name is in bold; see text for the rationale behind these recommendations. For each generic name this list provides the author, its date and place of publication, type species of the genus, its basionym, their dates of publication and the currently accepted name, if different. The action required is indicated in the last column such as approval by the Nomenclature Committee for Fungi (NCF) for those generic names that do not have priority and thus need protection.

\begin{tabular}{|c|c|c|}
\hline Recommended generic name & Synonymous alternate morph generic name(s) & Action required \\
\hline $\begin{array}{l}\text { Basidiopycnis Oberw. et al. in Mycologia 98: } 639 . \\
2006 . \\
\text { Type: B. hyalina Oberw. et al. } 2006 .\end{array}$ & $\begin{array}{l}\text { Basidiopycnides J. Reid et al. in Mycotaxon 103: } 285 . \\
2008 . \\
\text { Type: B. albertensis J. Reid et al. 2008, now regarded } \\
\text { as Basidiopycnis hyalina Oberw. et al. } 2006 .\end{array}$ & None. \\
\hline $\begin{array}{l}\text { Blastospora Dietel in Ann. Mycol. 6: 222. } 1908 . \\
\text { Type: B. smilacis Dietel } 1908 .\end{array}$ & $\begin{array}{l}\text { Pelastoma M. Salazar et al. in Mycologia 104: } 116 . \\
2012 . \\
\text { Type: P. juruensis (Henn.) M. Salazar et al. 2012, } \\
\text { basionym: Uredo juruensis Henn. 1904, now } \\
\text { regarded as Blastospora juruensis (Henn.) Aime \& } \\
\text { Rossman 2018. }\end{array}$ & None. \\
\hline $\begin{array}{l}\text { Camptobasidium Marvanová \& Suberkr. in Mycologia } \\
\text { 82: 209. } 1990 . \\
\text { Type: C. hydrophilum Marvanová \& Suberkr. } 1990 .\end{array}$ & $\begin{array}{l}\text { Crucella Marvanová \& Suberkr., Mycologia 82: 212, } \\
1990 . \\
\text { Type: C. subtilis Marvanová \& Suberkr. 1990, } \\
\text { now regarded as Camptobasidium hydrophilum } \\
\text { Marvanová \& Suberkr. } 1990 .\end{array}$ & None. \\
\hline $\begin{array}{l}\text { Classicula R. Bauer et al. in Mycologia 95: 757. } 2003 . \\
\text { Type: C. fluitans et al. } 2003 .\end{array}$ & $\begin{array}{l}\text { Naiadella Marvanová \& Bandoni in Mycologia 79: } \\
\text { 579. } 1987 . \\
\text { Type: } N \text {. fluitans Marvanová \& Bandoni 1987, now } \\
\text { regarded as Classicula fluitans R. Bauer et al. } 2003 .\end{array}$ & Protection needed by NCF. \\
\hline $\begin{array}{l}\text { Cronartium Fr., Observ. Mycol. 1: 220. } 1815 . \\
\text { Type: C. asclepiadeum (Willd.) Fr. 1815, basionym: } \\
\text { Erineum asclepiadeum Willd. 1806, now regarded } \\
\text { as Cronartium flaccidum (Alb. \& Schwein.) G. Winter } \\
\text { 1880. }\end{array}$ & $\begin{array}{l}\text { Endocronartium Y. Hirats. in Canad. J. Bot. 47: } 1493 . \\
1969 . \\
\text { Type: E. harknessii (J.P. Moore) Y. Hirats. 1969, } \\
\text { basionym: Peridermium harknessii J.P. Moore 1884, } \\
\text { now regarded as Cronartium harknessii (J.P. Moore) } \\
\text { E. Meinecke 1920. }\end{array}$ & None. \\
\hline $\begin{array}{l}\text { Elateraecium Thirum. et al. in Mycologia 58: } 394 . \\
1966 . \\
\text { Type: E. salaciicola Thirum. et al. } 1966 .\end{array}$ & $\begin{array}{l}\text { Hiratsukamyces Thirum. et al. Sydowia 27: 80, } 1975 . \\
\text { Type: H. salaciicola Thirum. et al. 1975, now regarded } \\
\text { as Elateraecium salaciicola Thirum. et al. } 1966 .\end{array}$ & None. \\
\hline $\begin{array}{l}\text { Gerwasia Racib. in Bull. Int. Acad. Sci. Cracovie, Cl. } \\
\text { Sci. Math. 3: } 270.1909 . \\
\text { Type: G. rubi Racib. } 1909 .\end{array}$ & $\begin{array}{l}\text { Morispora Salazar-Yepes et al. in Caldasia 29: } 108 . \\
2007 . \\
\text { Type: M. tenella (H.S. Jacks. \& Holw.) Salazar-Yepes } \\
\text { et al. 2007, basionym: Mainsia tenella H.S. Jacks. \& } \\
\text { Holw. 1931, now regarded as Gerwasia tenella (H.S. } \\
\text { Jacks. \& Holw.) Buriticá 1994. }\end{array}$ & None. \\
\hline $\begin{array}{l}\text { Gymnosporangium R. Hedw. ex DC., in Lamarck \& } \\
\text { de Candolle, Fl. franç., ed. } 3 \text { 2: } 216.1805 . \\
\text { Type: G. fuscum DC. } 1805 \text {, now regarded as } \\
\text { Gymnosporangium sabinae (Dicks.) G. Winter } 1884 .\end{array}$ & $\begin{array}{l}\text { Roestelia Rebent., Prodr. fl. neomarch.: } 350.1804 . \\
\text { Type: R. cancellata (Pers.) Rebent. 1804, basionym: } \\
\text { Aecidium cancellatum Pers. 1792, now regarded as } \\
\text { Gymnosporangium sabinae (Dicks.) G. Winter } 1884 .\end{array}$ & Protection needed by NCF. \\
\hline $\begin{array}{l}\text { Helicobasidium Pat. in Bull. Soc. Bot. France 32: } \\
\text { 172. } 1885 . \\
\text { Type: H. purpureum (Tul.) Pat. 1885, basionym: } \\
\text { Hypochnus purpureus Tul. } 1865 .\end{array}$ & $\begin{array}{l}\text { Thanatophytum Nees, Syst. Pilze: 148. } 1816 . \\
\text { Type: T. crocorum (Pers.) Nees 1816, basionym: } \\
\text { Sclerotium crocorum Pers. 1801, now regarded as } \\
\text { Helicobasidium purpureum (Tul.) Pat. 1885. } \\
\text { Tuberculina Tode ex Sacc. in Michelia 2: } 34.1881 . \\
\text { Type: T. persicina (Ditmar) Sacc. 1881, basionym: } \\
\text { Tubercularia persicina Ditmar 1817, now regarded as } \\
\text { Helicobasidium purpureum (Tul.) Pat. } 1885 .\end{array}$ & Protection needed by NCF. \\
\hline $\begin{array}{l}\text { Hyalopycnis Höhn. in Hedwigia 60: 152. } 1918 . \\
\text { Type: H. hyalina Höhn. 1918, now regarded as } \\
\text { Heterogastridium pycnidioideum Oberw. \& R. Bauer } \\
\text { 1990. }\end{array}$ & $\begin{array}{l}\text { Heterogastridium Oberw. \& R. Bauer in Mycologia 82: } \\
\text { 57. } 1990 . \\
\text { Type: H. pycnidioideum Oberw. \& R. Bauer } 1990 .\end{array}$ & None. \\
\hline
\end{tabular}


Table 1. (Continued).

\begin{tabular}{|c|c|c|}
\hline Recommended generic name & Synonymous alternate morph generic name(s) & Action required \\
\hline $\begin{array}{l}\text { Kriegeria Bres. in Rev. Mycol. (Toulouse) 13: } 14 . \\
1891 . \\
\text { Type: K. eriophori Bres. } 1891 .\end{array}$ & $\begin{array}{l}\text { Xenogloea Syd. \& P. Syd. in Ann. Mycol. 17: } 44 . \\
1919 . \\
\text { Type: X. eriophori (Bres.) Syd. \& P. Syd. 1919, } \\
\text { basionym: Kriegeria eriophori Bres. } 1891 . \\
\text { Zymoxenogloea D.J. McLaughlin \& Doublés in } \\
\text { Mycologia 84: 671. } 1992 . \\
\text { Type: Z. eriophori D.J. McLaughlin \& Doublés 1992, } \\
\text { now regarded as Kriegeria eriophori Bres. 1891. }\end{array}$ & None. \\
\hline $\begin{array}{l}\text { Kuehneola Magnus in Bot. Centralbl. 74: 169. } 1898 . \\
\text { Type: K. albida (J.G. Kühn) Magnus 1898, basionym: } \\
\text { Chrysomyxa albida J.G. Kühn 1883, now regarded as } \\
\text { Kuehneola uredinis (Link) Arthur 1906. }\end{array}$ & $\begin{array}{l}\text { Spirechina Arthur in J. Mycol. 13: 30. } 1907 . \\
\text { Type: S. loeseneriana (Henn.) Arthur 1907, basionym: } \\
\text { Uredo loeseneriana Henn. 1898, now regarded as } \\
\text { Kuehneola loeseneriana (Henn.) H.S. Jacks. \& Holw. } \\
1931 .\end{array}$ & None. \\
\hline $\begin{array}{l}\text { Melampsorella J. Schröt. in Hedwigia 13: 85. } 1874 . \\
\text { Type: M. caryophyllacearum (DC.) J. Schröt. 1874, } \\
\text { basionym: Uredo caryophyllacearum DC. } 1805 .\end{array}$ & $\begin{array}{l}\text { Peridermium (Link) J.C. Schmidt \& Kunze in } \\
\text { Deutschl. Schwämme 6: 4. 1817, basionym: } \\
\text { Hypodermium subgen. Peridermium Link } 1816 . \\
\text { Type: Aecidium elatinum Alb. \& Schwein. 1805, now } \\
\text { regarded as Melampsorella caryophyllacearum (DC.) } \\
\text { J. Schröt. } 1874 .\end{array}$ & Protection needed by NCF. \\
\hline $\begin{array}{l}\text { Milesina Magnus in Ber. Deutsch. Bot. Ges. 27: } 325 . \\
1909 . \\
\text { Type: M. kriegeriana (Magnus) Magnus 1909, } \\
\text { basionym: Melampsorella kriegeriana Magnus } 1901 .\end{array}$ & $\begin{array}{l}\text { Milesia F.B. White in Scott. Nat. 4: 162. } 1878 . \\
\text { Type: M. polypodii F.B. White 1878, now regarded as } \\
\text { Milesina polypodii (F.B. White) Aime \& Rossman } 2018 .\end{array}$ & Protection needed by NCF. \\
\hline $\begin{array}{l}\text { Phragmidium Link in Ges. Naturf. Freunde Berlin } \\
\text { Mag. 7: } 30.1816 . \\
\text { Type: P. mucronatum (Pers.) Schltdl. 1824, basionym: } \\
\text { Puccinia mucronata Pers. } 1794 .\end{array}$ & $\begin{array}{l}\text { Aregma Fr., Observ. Mycol. 1: 22., } 1815 . \\
\text { Type: A. obtusatum Fr. 1832, now regarded as } \\
\text { Phragmidium fragariae (DC.) G. Winter 1884, } \\
\text { basionym: Puccinia fragariae DC., } 1808 . \\
\text { Lecythea Lév. in Ann. Sci. Nat., Bot., sér. } 3 \text { 8: 373. } 1847 . \\
\text { Type: L. miniata (Pers.) Lév. 1847, basionym: Uredo } \\
\text { miniata Pers. 1801, now regarded as Phragmidium } \\
\text { mucronata (Pers.) Schltdl. 1824. }\end{array}$ & Protection needed by NCF. \\
\hline $\begin{array}{l}\text { Prospodium Arthur in J. Mycol. 13: 31. } 1907 . \\
\text { Type: P. appendiculatum (G. Winter) Arthur 1907, } \\
\text { basionym: Dicaeoma appendiculata Kuntze } 1898 .\end{array}$ & $\begin{array}{l}\text { Canasta A.A. Carvalho \& J.F. Hennen in Mycologia } \\
\text { 102: 1096. } 2010 . \\
\text { Type: C. cruscula A.A. Carvalho \& J.F. Hennen 2010, } \\
\text { now regarded as Prospodium cruscula (A.A. Carvalho } \\
\text { \& J.F. Hennen) Aime \& Rossman 2018. }\end{array}$ & None. \\
\hline $\begin{array}{l}\text { Puccinia Pers. in Neues Mag. Bot. 1: 118. } 1794 . \\
\text { Type: P. graminis Pers. } 1794 .\end{array}$ & $\begin{array}{l}\text { Aecidium Pers., Observ. Mycol. 1: } 97.1796 . \\
\text { Type: A. berberidis Pers. } 1796, \text { now regarded as } \\
\text { Puccinia graminis Pers. } 1794 . \\
\text { Caeoma Link in Ges. Naturf. Freunde Berlin Mag. 3: } \\
\text { 5. } 1809 . \\
\text { Type: C. berberidis (Pers.) Har. 1809, basionym: } \\
\text { Aecidium berberidis Pers. } 1792, \text { now regarded as } \\
\text { Puccinia graminis Pers. } 1794 .\end{array}$ & None. \\
\hline $\begin{array}{l}\text { Rhodotorula F.C. Harrison in Proc. \& Trans. Roy. } \\
\text { Soc. Canada, ser. } 3 \text { 21: 349. } 1927 . \\
\text { Type: R. glutinis (Fresen.) F.C. Harrison } 1928 .\end{array}$ & $\begin{array}{l}\text { Chromotorula F.C. Harrison in Proc. \& Trans. Roy. } \\
\text { Soc. Canada, ser. } 3 \text { 21: } 350.1927 . \\
\text { Type: C. kitae F.C. Harrison } 1927 . \\
\text { Rhodosporidium Banno in J. Gen .Appl. Microbiol. 13: } \\
\text { 192. } 1967 . \\
\text { Type: R. toruloides Banno 1967, now regarded as } \\
\text { Rhodotorula toruloides (Banno) Q.M. Wang et al. } 2015 .\end{array}$ & None. \\
\hline $\begin{array}{l}\text { Septobasidium Pat. in J. Bot. (Morot) 6: 63. } 1892 . \\
\text { Type: S. velutinum Pat. } 1892 .\end{array}$ & $\begin{array}{l}\text { Johncouchia S. Hughes \& Cavalc. in Canad. J. Bot. } \\
\text { 61: } 2226.1983 . \\
\text { Type: J. mangiferae (Bat.) S. Hughes \& Cavalc. 1983, } \\
\text { basionym: Cladotrichum mangiferae Bat. 1956, now } \\
\text { regarded as Septobasidium pilosum Boedijn \& B.A. } \\
\text { Steinm. 1930. }\end{array}$ & None. \\
\hline
\end{tabular}


Table 1. (Continued).

\begin{tabular}{|c|c|c|}
\hline Recommended generic name & Synonymous alternate morph generic name(s) & Action required \\
\hline $\begin{array}{l}\text { Sporobolomyces Kluyver \& C.B. Niel in Centralbl. } \\
\text { Bakteriol., } 2 \text { Abt. 2: 63. } 1924 . \\
\text { Type: S. salmonicolor (B. Fisch. \& Brebeck) Kluyver \& } \\
\text { C.B. Niel 1924, basionym: Blastoderma salmonicolor } \\
\text { B. Fisch. \& Brebeck 1894. }\end{array}$ & $\begin{array}{l}\text { Aessosporon Van der Walt in Antonie van } \\
\text { Leeuwenhoek 36: } 54.1970 . \\
\text { Type: A. salmonicolor Van der Walt 1970, now } \\
\text { regarded as Sporobolomyces salmonicolor (B. Fisch. } \\
\text { \& Brebeck) Kluyver \& C.B. Niel 1924. } \\
\text { Blastoderma B. Fisch. \& Brebeck, in Fischer, Morph. } \\
\text { Syst.: 47. 1894. } \\
\text { Type: B. salmonicolor B. Fisch. \& Brebeck 1894, now } \\
\text { regarded as Sporobolomyces salmonicolor (B. Fisch. } \\
\text { \& Brebeck) Kluyver \& C.B. Niel 1924. } \\
\text { Rhodomyces Wettst. in Sitzungsber. Kaiserl. Akad. } \\
\text { Wiss., Wien, Math.-naturw. Kl., Abt. 191: 39. 1885. } \\
\text { Type: R. kochii Wettst. 1885, now regarded as } \\
\text { Sporobolomyces salmonicolor (B. Fisch. \& Brebeck) } \\
\text { Kluyver \& C.B. Niel 1924. } \\
\text { Sporidiobolus Nyland in Mycologia 41: 686. 1950. } \\
\text { Type: S. johnsonii Nyland 1950, now regarded as } \\
\text { Sporobolomyces johnsonii (Nyland) Q.M. Wang et al. } \\
\text { 2015. }\end{array}$ & Protection needed by NCF. \\
\hline $\begin{array}{l}\text { Uromyces (Link) Unger, Exanth. Pflanzen: } 277 . \\
1833 \text { (nom. cons.), basionym: Hypodermium subgen. } \\
\text { Uromyces Link } 1816 . \\
\text { Type: U. appendiculata (Pers.) Unger 1796, basionym: } \\
\text { Uredo appendiculatus Pers., now regarded as: } \\
\text { Uromyces appendiculatus (Pers.) Link } 1816 .\end{array}$ & $\begin{array}{l}\text { Uredo Pers., Syn. Meth. Fung. 1: 214. } 1801 . \\
\text { Type: U. betae Pers. 1801, now regarded as } \\
\text { Uromyces beticola (Bellynck) Boerema, Loer. \& } \\
\text { Hamers } 1987 .\end{array}$ & Protection needed by NCF. \\
\hline
\end{tabular}

clarified the terminology associated with them, thus these generic names are synonyms. Given that Basidiopycnis has priority and both generic names are monotypic and relatively obscure (GS Basidiopycnis $=37$, Basidiopycnides $=5$ ), we follow the principle of priority and recommend the use of Basidiopycnis.

\section{Use Blastospora Dietel 1908 (S) rather than Pelastoma Salazar-Yepes et al. 2012 (A)}

The generic name Blastospora typified by $B$. smilacis includes tropical heteroecious rust fungi as summarized by Salazar-Yepes et al. (2012) who described Pelostoma typified by $P$. juruense for the asexual morph of $B$. columbiana (syn. Hemileia columbiana). Aime (2006) demonstrated that $B$. smilicis has affinities to Hemileia and Maravalia in the Mikronegeriaceae. Blastospora smilacis and B. itoana were considered to have asexual morphs belonging to Caeoma (Ono et al. 1986, 1987); however, the type of Caeoma is C. berberidis, a synonym of Puccinia graminis, thus Caeoma is a synonym of Puccinia. No other species of Blastospora nor the second species of Pelostoma have been sequenced. Assuming that $B$. columbiana is congeneric with $B$. smilicis, then Blastospora and Pelostoma are synonyms. At present five species are included in Blastospora and one name additional to the type has been placed in Pelostoma. Considering the fact that Blastospora has priority, a greater number of names, and is more commonly used (GS Blastospora $=567$, Pelastoma $=11$ ), we recommend the use of Blastospora for this genus.
Two new combinations are required:

Blastospora juruensis (Henn.) Aime \& Rossman, comb. nov.

MycoBank MB824643

Basionym: Uredo juruensis Henn., Hedwigia 43: 161 (1904). Synonyms: Hemileia juruensis (Henn.) P. Syd. \& Syd., Mon. Ured. 3: 219 (1915).

Hemileia jahnii Syd., Ann. Mycol. 28: 46 (1930).

Uredo jahnii (Syd.) Ritschel, Biblioth. Mycol. 200: 98 (2005).

Hemileia colombiana Buriticá, Caldasia 12: 165 (1978).

Blastospora colombiana (Buriticá) Salazar-Yepes et al., Mycologia 104: 116 (2012).

Blastospora subneurophyla (Speg.) Aime \& Rossman, comb. nov.

MycoBank MB824644

Basionym: Uredo subneurophyla Speg., Anales Soc. Ci. Argent. 17: 123 (1883).

Synonyms: Puccinia subneurophyla (Speg.) Speg., Anales Mus. Nac. Hist. Nat. Buenos Aires 31: 384 (1922).

Pelastoma subneurophylum (Speg.) Salazar-Yepes et al., Mycologia 104: 116 (2012).

Uredo forsteroniae Henn., Hedwigia 34: 99 (1895).

Use Camptobasidium Marvanová \& Suberkr. 1990 (S) rather than Crucella Marvanová \& Suberkr. 1990 (A) 
Table 2. Recommended generic names of Ustilaginomycotina among sexual-asexual names that compete for use. The recommended name is in bold; see text for the rationale behind these recommendations. For each generic name this list provides the author, its date and place of publication, type species of the genus, its basionym, their dates of publication and the currently accepted name, if different. The action required is indicated in the last column such as approval by the Nomenclature Committee for Fungi (NCF) for those generic names that do not have priority and thus need protection.

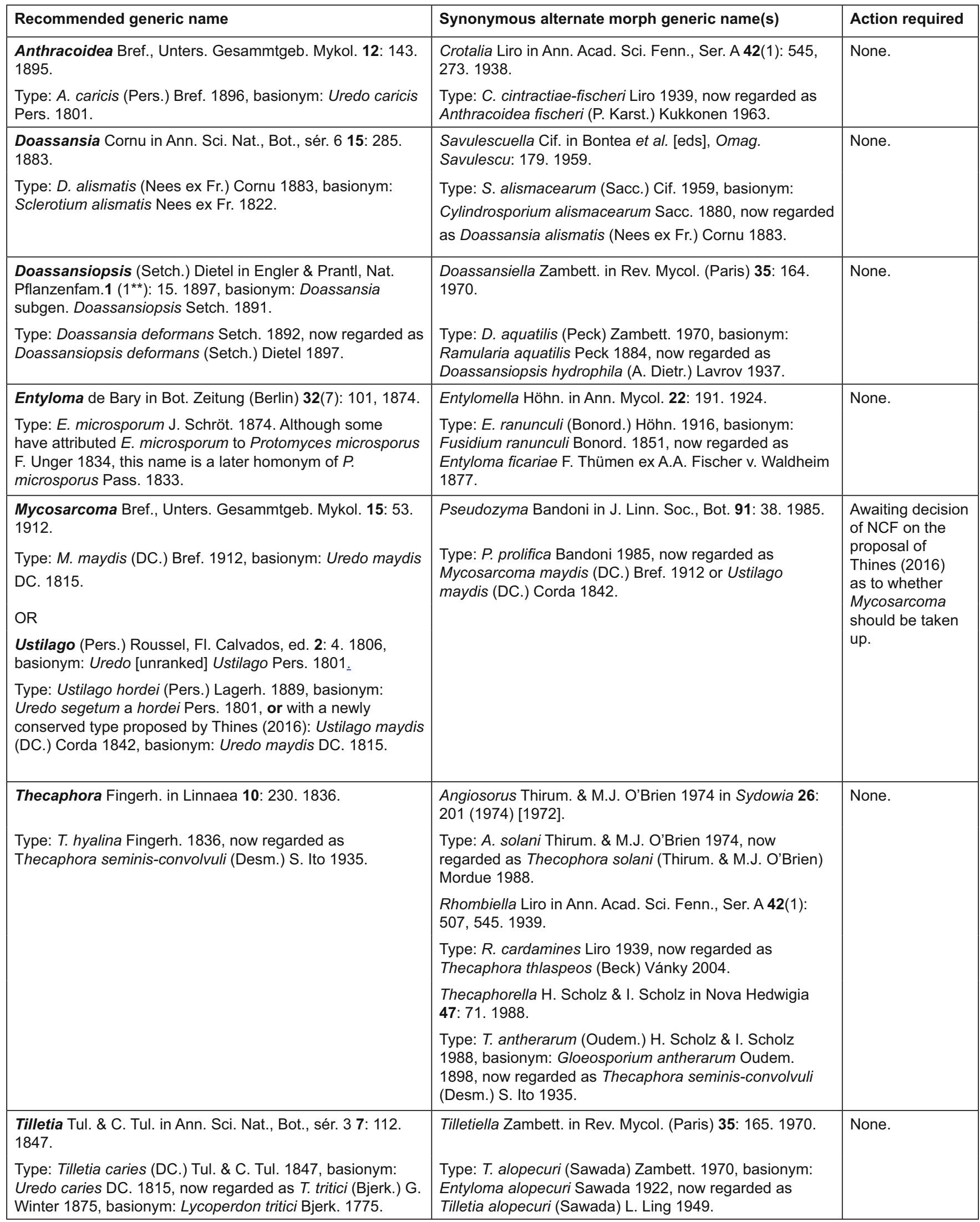


Table 2. (Continued).

\begin{tabular}{|l|l|l|}
\hline Recommended generic name & Synonymous alternate morph generic name(s) & Action required \\
\hline $\begin{array}{l}\text { Urocystis Rabenh. ex Fuckel in Jahrb. Nassauischen } \\
\text { Vereins Naturk. 23-24: 41. } 1870 \text { (nom. cons.). }\end{array}$ & Paepalopsis J.G. Kühn in Irmischia 7: 39, 1882. & None. \\
$\begin{array}{l}\text { Type: U. occulta (Wallr.) A.A. Fisch. Waldh. 1867, basionym: } \\
\text { Erysibe occulta Wallr. 1833. }\end{array}$ & $\begin{array}{l}\text { Type: P. irmischiae J.G. Kühn 1882, now regarded as } \\
\text { Urocystis primulae (Rostr.) Vánky 1985. } \\
\text { Polycystis Lév. in Ann. Sci. Nat. Bot., Ser. 3, 5: 269. 1846. } \\
\text { Type: P. pompholygodes Lév. 1846, now regarded as } \\
\text { Urocystis anemones (Pers.) G. Winter 1880. }\end{array}$ & \\
\end{tabular}

The generic names Camptobasidium and Crucella were described in the same article based on sexually and asexually typified morphs of the same species, thus they are synonyms and compete equally for use (Marvanová \&. Suberkropp 1990). Both are monotypic and have been used to the same extent, although Crucella is also the name of a fossil radiolarian, thus it is difficult to determine its usage as a fungus. Given the confusion about the use of the name Crucella and because preference has previously been given to sexual morph names, we recommend the use of Camptobasidium.

\section{Protect Classicula R. Bauer et al. 2003 (S) over Naiadella Marvanová \& Bandoni 1987 (A)}

The monotypic generic name Classicula is typified by $C$. fluitans, which was described as the sexual morph of $N$. fluitans (Bauer et al. 2003), the type species of the monotypic generic name Naiadella, thus these names are synonyms. Neither name is frequently used (GS Classicula = 73; Naiadella = 86); however, the family Classiculaceae, order Classiculales, and class Classiculomycetes are based on the name Classicula, thus we recommend the use of Classicula.

\section{Use Cronartium Fr. 1815 (S) rather than Endocronartium Y. Hirats. 1969 (S)}

The generic name Cronartium is well known for species that cause stem rusts on conifers in temperate regions, often with alternate hosts on herbaceous plants. One of the most notorious species is $C$. flaccidum, cause of Scots pine blister rust, of which C. asclepiadeum, the type species of Cronartium, is a synonym (Mordue \& Gibson 1978). Endocronartium was established for species genetically similar to Cronartium except for being autoecious (i.e. completing their life-cycle on a single host) and endocyclic (lacking aecia and uredinia and having aecioid telia) (Hiratsuka 1969). The type species of Endocronartium, E. harknessii, cause of western gall rust, has long been known to be indistinguishable from species of Cronartium except for the life-cycle reductions (Epstein \& Buurlage 1988). With the change in the ICN, these generic names are synonyms and the six taxa of Endocronartium should be recognized in the older, commonly used genus Cronartium.

All species of Endocronartium have been shown to belong in the genus Cronartium either as synonyms or distinct species within that genus. Several new combinations are made below. In addition, Endocronartium pini (Willd.) Y. Hirats. (syn. Peridermium pini (Willd.) Lév.) has been shown to be a synonym of $C$. flaccidum (Hantuka et al. 2002).

Although some of the asexual morphs of species of Cronartium have been recognized in Peridermium, that generic name is now regarded as a synonym of Melampsorella based on the type species, Aecidium elatinum, which is a later name for M. caryophyllacearum (see below under Melampsorella). Thus, names in Peridermium must be recognized in the sexually typified genus in which the species belong, primarily Cronartium but also Chrysomyxa and Coleosporium.

The following new combinations are required:

Cronartium bethelii (Hedgc. \& Long) Aime \& Rossman, comb. nov.

MycoBank MB824645

Basionym: Peridermium bethelii Hedgc. \& Long, Phytopathology 3: 251 (1913).

Vogler \& Bruns (1998) demonstrated that Peridermium bethelii belongs in Cronartium, as sister to C. comandrae. With the change in the ICN, it is possible to place this name in Cronartium.

Cronartium kurilense (Dietel) Y. Ono, comb. nov. MycoBank MB824647

Basionym: Peridermium kurilense Dietel, Bot. Jahrb. Syst. 37: 107 (1905),

Synonym: Endocronartium sahoanum var. hokkaidoense Imazu \& Kakish., Trans. Mycol. Soc. Japan 33: 174 (1992).

A blister rust fungus on Pinus pumila in the North Kuril Islands (southeast of Kamchatka, Russia) was described as Peridermium kurilense, distinct from C. ribicola (Dietel 1905). It was subsequently synonymized under C. kamtschaticum (Jørstad 1934, Hiratsuka et al. 1992). An endocyclic fungus on Pinus pumila distributed in northern Honshu, Japan, was named as E. sahoanum (Imazu et al. 1989), and a similar fungus on the same host species distributed in Hokkaido was separated as a variety, E. sahoanum var. hokkaidoense, distinct from $E$. sahoanum var. sahoanum on the basis of differences in spore and germ tube morphology (Imazu \& Kakishima 1992). Based on the similarity in spore shape, size, surface structure, and PCR-RFLP pattern, $P$. kurilense and $E$. sahoanum var. hokkaidoense have been shown to be conspecific and distinct from C. kamtschaticum, which is now considered a synonym of C. ribicola (Imazu et al. 2000, Kim et al. 2010). Thus, P. kurilense must be placed in Cronartium. 
Cronartium sahoanum (Imazu \& Kakish.) Aime \& Rossman, comb. nov.

MycoBank MB824648

Basionym: Endocronartium sahoanum Imazu \& Kakish. Trans. Mycol. Soc. Japan 30: 308 (1989).

Cronartium yamabense (Saho \& I. Takah.) Aime \& Rossman, comb. nov.

MycoBank MB824649

Basionym: Peridermium yamabense Saho \& I. Takah., Trans. Mycol. Soc. Japan 22: 33 (1981).

Synonym: Endocronartium yamabense (Saho \& I. Takah.) Paclt, Mitt. Deutsch. Dendrol. Ges. 77: 227 (1987).

\section{Use Elateraecium Thirum. et al. 1966 (A) rather than Hiratsukamyces Thirum. et al. 1975 (S)}

The generic name Hiratsukamyces, typified by $H$. salaciicola, was established for the sexual morph of Elateraecium salaciicola, type species of Elateraecium (Thirumalachar et al. 1966, 1975), thus these generic names are synonyms. Two names were included in Hiratsukamyces when it was described, each also having a name in Elateraecium for the asexual morph. Since then two more names have been added to Elateraecium by Gjaerum \& Reid (1983). Both generic names are obscure but given the greater number of names, priority, and slightly greater use (GS Elateraecium $=12$, Hiratsukamyces =11), we recommend the use of Elateraecium.

\section{Use Gerwasia Racib. 1909 (S) rather than Morispora Salazar-Yepes et al. 2007 (A)}

Gerwasia, typified by $G$. rubi, is a well-known genus of autoecious rust fungi that occurs on Rosaceae, primarily in the Asian and American tropics (Cummins \& Hiratsuka 2003). Twenty-two species have been described in Gerwasia of which 12 have asexual morphs that have been placed in Morispora, typified by M. tenella, a species with a sexual morph regarded as G. tenella (Salazar-Yepes et al. 2007). Thus, assuming that $G$. rubi and $G$. tenella are congeneric as indicated by Salazar-Yepes et al. (2007) but without molecular data, Gerwasia and Morispora are synonyms. All names in Morispora already have a name in Gerwasia. Given its priority, greater number of names, and widespread use (GS Gerwasia = 112, Morispora =6), the generic name Gerwasia is recommended for use.

Protect Gymnosporangium R. Hedw. ex DC. 1805 (S) over Roestelia Rebent. 1804 (A)

The genus Gymnosporangium, based on G. fuscum, now recognized as $G$. sabinae, includes ubiquitous rust fungi that have been well-studied (Yun et al. 2009). Index Fungorum lists 145 names in this genus. The type species of Roestelia, $R$. cancellata, is a synonym of G. sabinae (Alexopoulos 1940, Kern 1973), thus these generic names are synonyms. Although 55 names have been placed in Roestelia, their sexual morphs belong primarily in Gymnosporangium. The need to protect Gymnosporangium was recognized many years ago; however, the proposal to conserve Gymnosporangium over Roestelia was rejected for lack of adequate justification (Rogers 1953). Because Gymnosporangium is by far the most commonly used name rather than Roestelia (GS Gymnosporangium $=6050$,
Roestelia $=598$ ) and includes a greater number of species, we recommend the protection of Gymnosporangium.

\section{Protect Helicobasidium Pat. 1885 (S) over Thanatophytum Nees 1816 (A) and Tuberculina Tode ex Sacc. 1880 (A)}

Helicobasidium, typified by H. purpureum, includes 15 species, some of which cause plant diseases, such as $H$. purpureum, the cause of cosmopolitan violet root rot, and the closely related $H$. mompa, also causing violet root rot in Africa and Asia (Sayama et al. 1994). The asexual morph of $H$. purpureum has been regarded as Thanatophytum crocorum (Roberts 1999). Two species were mentioned in the protolog for Thanatophytum; Donk (1962) lectotypified this genus with T. crocorum. The generic name Tuberculina is lecto-typified by T. persicina (Clements \& Shear 1931), a parasite of rust fungi. The relationship between these names all representing the same species was confirmed by Lutz et al. (2004) in which the life strategy of this unusual fungus was clarified. More specifically, they determined that T. persicina is a synonym of Helicobasidium purpureum. The commonly used name $H$. purpureum based on Hypochnus purpureus is herein proposed for protection over the older names Sclerotium crocorum and Tubercularia persicina. Among these three generic names, Helicobasidium is most commonly used (GS Helicobasidium $=2090$, Thanatophytum $=67$, Tuberculina $=487$ ). Given the widespread use of Helicobasidium and the number of species in this genus, we recommend Helicobasidium for protection. In addition we recommend the name of the type species, $H$. purpureum, for protection.

\section{Name for protection:}

Helicobasidium purpureum (Tul.) Pat., Bull. Soc. Bot. France 32: 171 (1885).

Basionym: Hypochnus purpureus Tul., Ann. Sci. Nat., Bot., sér. 5 4: 295 (1865); nom. prot. prop.

Rejected names and synonyms: Tuber parasiticum Bull., Hist. champ. France 1: 81 (1791).

Sclerotium crocorum Pers., Syn. meth. fung. 1: 119 (1801).

Rhizoctonia crocorum (Pers.) DC., in De Candolle \& Lamarck, Fl. franç., $3^{\text {rd }}$ edn 5: 110 (1815).

Thanatophytum crocorum (Pers.) Nees, Syst. Pilze: 148 (1816) [“1816-17"].

Rhizoctonia medicaginis DC., in De Candolle \& Lamarck, FI. franç., $3^{\text {rd }}$ edn 5: 111 (1815).

Tubercularia persicina Ditmar, in Sturm, Deutschl. Fl., Abt. 3 1: 99 (1817).

Tuberculina persicina (Ditmar) Sacc., Fungi italice autogr. del. 17-28: tab. 964 (1881).

Protonema brebissonii Desm., PI. crypt. N. France: no. 651 (1834).

Helicobasidium brebissonii (Desm.) Donk, Taxon 7: 164 (1958).

Rhizoctonia rubiae M.J. Decne., Rech. Anat. Physiol. Garance: 55 (1837).

Rhizoctonia violacea Tul. \& C. Tul., Fung. hypog.: 188 (1851).

Among the extensive list of synonymous names, Helicobasidium purpureum is the name in Helicobasidium most commonly used for this important and ubiquitous 
plant pathogen (GS Helicosporium purpureum $=627, \mathrm{H}$. berbissonii $=7$ ). Although several names for this fungus have been placed in Rhizoctonia, the type species of Rhizoctonia is $R$. solani, which represents a genus in Agaricomycotina.

\section{Use Hyalopycnis Höhn. 1918 (A) rather than} Heterogastridium Oberw. \& R. Bauer 1990 (S) The generic name Hyalopycnis is typified by $H$. hyalina. Hyalopycnis blepharistoma, a synonym of $H$. hyalina, was regarded as the asexual morph of Heterogastridium pycnidioidium, the type of the monotypic generic name Heterogastridium as explained by Oberwinkler et al. (1990) in describing the order Heterogastridiales, now placed in Microbotryomycetes, Pucciniomycotina (Aime et al. 2006, Toome \& Aime 2014). Thus, the generic names Heterogastridium and Hyalopycnis are synonyms. Although the generic name Heterogastridium has been used slightly more frequently (GS Heterogastridium $=54$, Hyalopycnis $=$ 43) and serves as the basis for the ordinal name, Hyalopycnis has priority and its use circumvents the need for a name change for the only species, thus we recommend the use of Hyalopycnis. Its use does not affect the ordinal name.

\section{Use Kriegeria Bres. 1891 (S) rather than Xenogloea Syd. \& P. Syd. 1919 (S) and Zymoxenogloea D.J. McLaughlin \& Doublés 1992 (A)}

The monotypic generic name Kriegeria Bres., typified by $K$. eriophori, was determined to be legitimate by Toome et al. (2015). Previously it has been confused with Kriegeria Höhnel 1914 and Kriegeria Rabenh. ex Seaver 1943, whose species are now placed in other genera in the ascomycete families Helotiaceae and Rutstroemiaceae. Kriegeria Bres. 1891 has also been confused with the later monotypic generic name Xenogloea typified by the same species, $X$. eriophori. An asexual morph of $K$. eriophori, as $X$. eriophori, was named Zymoxenogloea eriophori, monotype species of Zymoxenogloea, thus Kriegeria Bres. 1891, Xenogloea, and Zymoxenogloea are synonyms. Following Toome et al. (2015) and priority, we recommend the use of Kriegeria.

\section{Use Kuehneola Magnus 1899 (S) rather than Spirechina Arthur 1907 (A)}

The generic name Kuehneola, typified by $K$. albida, now regarded as $K$. uredinis (Ono 2015), includes about 25 species of rust fungi that occur primarily on species of Rubus and other Rosaceae (Cummins \& Hiratsuka 2003). The generic name Spirechina, typified by $S$. loeseneriana, has been used for the asexual morph of species of Kuehneola and Gerwasia. Spirechina loeseneriana is regarded as the asexual morph of $K$. loeseneriana (Jackson 1931). Although 13 species had been named in Spirechina, all have been placed in Gerwasia, Kuehneola, or Mainsia (Kirk 2017). Given its priority, greater number of names, and more frequent use (GS Kuehneola $=590$, Spirechina $=42$ ), we recommend Kuehneola for use.

Protect Melampsorella J. Schröt. 1874 (S) over Peridermium (Link) J.C. Schmidt \& Kunze 1817 (A)
The type species of Melampsorella is $M$. caryophyllacearum, while Peridermium is typified with the conserved type, Aecidium elatinum, as formally proposed by Hiratsuka (1974) and approved (Petersen 1975). Because the latter is regarded as a synonym of M. caryophyllacearum (Hiratsuka 1974), these generic names are synonyms. Melampsorella has five names in Index Fungorum. The asexually typified generic name Peridermium includes many species most of which have sexual morphs in Cronartium (Vogler \& Bruns 1998). Given the relationship of species of Peridermium with both Melampsorella and Cronartium, we recommend abandoning the name Peridermium in favour of Melampsorella.

Although the type species of Peridermium dictates that this generic name is a synonym of Melampsorella, a number of names introduced in Peridermium belong in other rust genera, such as Cronartium, Coleosporium and several genera of Pucciniastraceae. An effort will be made to determine the correct generic placement of species described in Peridermium. Furthermore, an asexual morph can still be referred to as peridermium-like, using the term in a non-latinized form to describe a morphology.

\section{Protect Milesina Magnus 1909 (S) over Milesia F.B. White 1878 (A)}

The genus Milesina includes over 60 species, primarily occurring on Abies alternating with ferns in several families. The type species, Milesina kriegeriana, occurs on Abies and Dryopteris in Europe and is known to have an asexual morph recognized as Milesia kriegeriana. The type species of Milesia is Milesia polypodii, recognized as the uredinial state of Milesina dieteliana (Laundon 1967), thus Milesina and Milesia are synonyms. Although Milesia is the older generic name and has about the same number of names as Milesina (72 vs. 67, respectively), Milesina is in broader use especially in recent literature (e.g. Berndt 2007, Kakishima et al. 2016, Klenke \& Scholler 2015, Smith 2015, Tanese \& Negrean 2007, Wingfield et al. 2004). For these reasons, we recommend the protection and use of Milesina.

One new combination is required:

Milesina polypodii (F.B. White) Aime \& Rossman, comb. nov.

MycoBank MB824650

Basionym: Milesia polypodii F.B. White, Scott. Naturaist (Perth). 4: 163 (1878) [“1877-1878"]

Synonyms: Milesina dieteliana (Syd. \& P. Syd.) Magnus, Ber. Deutsch. Bot. Ges. 27: 325 (1909).

Melampsorella dieteliana Syd. \& P. Syd., Ann. Mycol. 1(6): 537 (1903).

Protect Phragmidium Link 1816 (S) over Aregma Fr. 1815 (S) and use rather than Lecythea Lév. 1847 (A)

The generic name Phragmidium is applied to a group of rust species that occur on Rosaceae. Recent molecular studies have shown that Phragmidium is a well-defined genus in Phragmidiaceae and that the type species of Phragmidium, $P$. mucronatum, is distinct from the other species commonly encountered on dog rose, P. tuberculatum (Ritz et al. 2005, 
Yun et al. 2011). Both those papers also demonstrated that $P$. mucronatum is congeneric but distinct from $P$. fragariae, the correct name for the type species of Aregma, A. obtusatum; thus, Aregma and Phragmidium are synonyms. Several species are mentioned in the protolog for Aregma; this genus was lectotypified by Laundon (1965).

The asexually typified generic name Lecythea is typified by $L$. miniata, based on Uredo miniata, and now regarded as a synonym of $P$. mucronatum. Although Lecythea includes 27 names, all but four have been placed in other genera (see Index Fungorum). Most of the 16 names in Aregma have been placed or have synonyms in Phragmidium, while 250 names have been described in Phragmidium; this generic name is much more commonly used than Aregma (GS Phragmidium $=3770$, Aregma $=244$ ). Given its common usage and greater number of names, we recommend that Phragmidium be protected.

\section{Use Prospodium Arthur 1907 (S) rather than Canasta A.A. Carvalho \& J.F. Hennen 2010 (A)}

The generic name Prospodium includes about 50 species occurring on Bignoniaceae and Verbenaceae in tropical regions (Cummins \& Hiratsuka 2003, Hernández \& Hennen 2003). The generic name Canasta was established for asexual morphs of species of Prospodium (Carvalho \& Hennen 2010), although the type species C. cruscula does not have a known sexual morph. Given that the other two names described in Canasta have sexual morphs that are species of Prospodium, it seems likely that Canasta is a synonym of Prospodium. Given its priority, greater number of species and widespread use, we recommend the use of Prospodium. One new combination is necessary:

\section{Prospodium crusculum (A.A. Carvalho \& J.F. Hennen) Aime \& Rossman, comb. nov. \\ MycoBank MB824651 \\ Basionym: Canasta cruscula A.A. Carvalho \& J.F. Hennen, Mycologia 102: 1098 (2010)}

\section{Use Puccinia Pers. 1794 (S) rather than Aecidium Pers. 1796 (A) and Caeoma Link 1809 (A)}

The generic name Puccinia is typified by $P$. graminis, the cause of the important wheat rust disease that has plagued this major food source throughout history (Schumann 1991). Several thousand names have been placed in Puccinia. The asexually typified generic name Aecidium is typified by $A$. berberidis, a name used for one of the alternate morphs of $P$. graminis (Cummins 1971), thus these generic names are synonyms. Prior to 2012, Aecidium was used when a sexual morph was lacking for rust fungi that appeared to have affinities with Puccinia. Before the changes in the ICN, the species could not be described in the "correct" genus (Puccinia) even though it was possible to determine its generic placement. The need for the generic name Aecidium no longer exists. The type species of Caeoma, C. berberidis, is a synonym of Puccinia graminis (Laundon 1967), thus Caeoma is a synonym of Puccinia. Given the ubiquitous use of the generic name Puccinia, it is recommended for use.
Use Rhodotorula F.C. Harrison 1928 (A) rather than Chromotorula F.C. Harrison 1928 (A) and Rhodosporidium Banno 1967 (S)

The type species of Rhodotorula, R. glutinis, was shown to be congeneric with Rhodosporidium toruloides, type of Rhodosporidium, by Wang et al. (2015a). They recognized the priority of Rhodotorula and placed Rhodosporidium toruloides in Rhodotorula. All 14 names described in Rhodosporidium have been placed in two genera, Rhodosporidiobolus and Rhodotorula. More than 150 names have been introduced in Rhodotorula. Chromotorula, typified by $C$. kitae, was published in the same article as Rhodotorula and thus has equal priority to Rhodotorula. Chromotorula has long been considered a synonym of Rhodotorula (StatzellTallman \& Fell 1998), and all but two of the six names in Chromotorula have been placed elsewhere. In agreement with Wang et al. (2015a) as well as priority, greater number of names, and most frequent use (GS Rhodotorula $=50300$, Rhodosporidium $=6130$ Chromotorula $=30$ ), we recommend the use of Rhodotorula.

Use Septobasidium Pat. 1892 (S) rather than Johncouchia S. Hughes \& Cavalc. 1983 (A)

The monotypic generic name Johncouchia, typified by J. mangiferae, was described for the asexual morph of Septobasidium pilosum (Hughes \& Cavalcanti 1983). Septobasidium pilosum and $S$. velutinum, the type species of Septobasidium, were determined to be congeneric by Henk \& Vilgalys (2007). Septobasidium includes over 300 names, has priority and is widely used (GS Septobasidium = 1200 , Johncouchia $=15$ ), and so we recommend the use of Septobasidium.

Septobasidium has already been formally conserved against Campylobasidium Lagerh. ex F. Ludw. 1892, Gausapia Fr. 1825, and Glenospora 1849.

Protect Sporobolomyces Kluyver \& C.B. Niel 1924 (A) over Blastoderma B. Fisch. \& Breback 1894 (A) and Rhodomyces Wettst. 1885 (A) and use rather than Aessosporon Van der Walt 1970 (S) and Sporidiobolus Nyland 1950 (S)

The generic name Sporobolomyces, typified by $S$. salmonicolor, includes about 100 names and is widely used. An earlier generic name, Rhodomyces, typified by $R$. kochii, is now considered a synonym of $S$. salmonicolor (Sampaio 2011). A second earlier monotypic generic name, Blastoderma, is typified by $B$. salmonicolor, the basionym of $S$. salmonicolor, thus these three generic names are synonyms. Another later name, Sporidiobolus, has six species, and is typified by $S$. johnsonii, a name now placed in Sporobolomyces (Wang et al. 2015a). The generic name Aessosporon, typified by $A$. salmonicolor, was described as the sexual morph of Sporobolomyces salmonicolor (Van der Walt 1970). Later authors showed that $A$. salmonicolor had the same heterothallic life-cycle and was conspecific with S. salmonicolor (Fell \& Statzell-Tallman 1980), thus Aesseosporon and Sporobolomyces are synonyms. Among these five generic names Blastoderma has rarely been used. Although the name Rhodomyces appears in the literature, 
the three described species are not closely related to the type, as shown by Wang et al. (2015a). A second species of Aessosporon, A. dendrophilum, was described as the sexual morph of Bullera dendrophilum (van der Walt 1973), but is now regarded as Kwoniella dendrophila in Agaricomycotina (Liu et al. 2015), and unrelated to Sporobolomyces. Because Sporobolomyces has priority, includes about 100 names and is widely used (GS Sporobolomyces $=10600$ Rhodomyces $=$ 183, Blastoderma $=523$, Sporidiobolus $=2970$, Aessosporon $=$ 171), we recommend that Sporobolomyces be protected over Rhodomyces and Blastoderma, and that Sporobolomyces be used rather than Sporidiobolus and Aessosporon.

\section{Protect Uromyces (Link) Unger 1833 (S) over Uredo Pers. 1801 (A)}

The generic name Uromyces, typified by $U$. appendiculatus, includes over 800 names. When Persoon (1801) described Uredo, he included 30 species, one of which was $U$. betae. Laundon (1970) reviewed the history of the typification of the generic name Uredo and concluded that $U$. betae should be accepted as the type of the genus. Uredo betae is now considered a synonym of Uromyces beticola (Boerema et al. 1987, Simpson et al. 2006). Uromyces appendiculatus and $U$. beticola are regarded as congeneric, although species of Uromyces are interspersed within Puccinia in Pucciniaceae (Aime 2006, Demers et al. 2017, Maier et al. 2003, Wingfield et al. 2004), thus Uromyces and Uredo are synonyms. Uredo includes over 2000 names, but is not as widely cited as Uromyces (GS Uromyces $=26$ 400, Uredo 7500). Thus, we recommend that Uromyces be protected over Uredo.

The generic name Uredo has been used for uredinial morphs of rust fungi belonging to multiple rust families, and does not reflect the affinities of species. Prior to 2011, this generic name was used when a sexual morph was lacking and the species could not be described in the "correct" sexually typified genus according the Code even when it was possible to determine its generic placement. Now that placement of fungi in genera is no longer restricted by whether their types are asxual or sexual morphs, in theory the need for the generic name Uredo no longer exists. However, in reality rust fungi are often found without the sexual morph and it can be difficult to determine their affinities; the issue of genera typified by a sexual morphs is discussed further above (p. 76).

The generic name Uromyces is already conserved over Coeomurus Link ex Gray 1821 and Pucciniola L. Marchand 1829.

\section{COMPETING SEXUAL AND ASEXUAL GE- NERIC NAMES OF USTILAGINOMYCOTINA, BASIDIOMYCOTA AND RECOMMENDATIONS FOR USE}

\section{Use Anthracoidea Bref. 1895 (S) rather than Crotalia Liro 1938 (A)}

The sexually typified genus Anthracoidea in Ustilaginales includes over 200 names, of which 90 are accepted in Vánky (2012), while the asexually typified Crotalia has five names, all of which also have names in Anthracoidea. The type species of Anthracoidea is A. caricis. Initially the type species of Crotalia, C. cintractiae-fischeri, was considered to be the asexual morph of Cintractia fischeri; however, that species is now regarded as Anthracoidea fischeri (Vánky 2012). Although $A$. fischeri was not included in Hendrichs et al. (2005), both $A$. caricis and $A$. fischeri are placed in Anthracoidea by Vánky (2012), thus Anthracoidea and Crotalia are synonyms.

Given its priority, the number of species, and more frequent citation in the literature (GS Anthracoidea $=619$, Crotalia $=234$ ), we recommend the use of Anthracoidea.

\section{Use Doassansia Cornu 1883 (S) rather than Savulescuella Cif. 1959 (A)}

The generic name Doassansia, typified by $D$. alismatis, includes about 12 species (Vánky 2012) while Savulescuella, typified by $S$. alismacearum, includes only three names. Vánky (2012) assumed that the asexual morph typified by S. alismacearum might be just "basidiospores of spores that germinated in situ", nevertheless Savulescuella was validly published. Currently, S. alismacearum is considered a synonym of $D$. alismatis, making these names generic synonyms. Given its priority, number of species, and widespread use (GS Doassansia $=457$, Savulescuella $=7$ ), we recommend the use of Doassansia.

\section{Use Doassansiopsis (Setch.) Dietel 1897 (S) rather than Doassansiella Zambett. 1970 (A)}

The generic name Doassansiopsis is typified by $D$. deformans. Sixteen additional names have been placed in this genus, most of which are accepted by Vánky (2012). The monotypic generic name Doassansiella is typified by $D$. aqualitis and has rarely been used. The type species is now regarded as Doassansiopsis hydrophila (Vánky 2012). Given the priority, number of species, and more extensive use (GS Doassansiopsis $=153$, Doassansiella $=2$ ), we recommend the use of Doassansiopsis.

Doassansiopsis in Urocystales should not be confused with Doassansia and Doassinga in the Doassansiales (Begerow et al. 2004).

\section{Use Entyloma de Bary 1874 (S) rather than Entylomella Höhn. 1924 (A)}

The generic name Entylomella was first mentioned by Höhnel (1916), although in that publication a description is lacking of either the genus or species although one species, E. ranunculi, is listed. Later in discussing Cylindrosporium, Höhnel (1924) mentioned Entylomella again as the conidial form of Entyloma and Doassansia species and two pages later provided a description of the type species as discussed by Braun (1995). Entylomella ranunculi is the type of Entylomella, which is now regarded as a synonym of Entyloma ficariae. The type species of Entyloma is E. microsporum. Begerow et al. (2002) demonstrated that $E$. ficariae and $E$. microsporum belong in Entyloma, thus Entylomella and Entyloma are synonyms. Over 400 names are listed in Entyloma and this generic name is well known (GS $=2410$ ) while 59 names have been described in Entylomella, many of which have been placed elsewhere, and the name has been used infrequently (GS $=60$ ). Given the priority, greater number of names, and familiarity, we recommend the use of Entyloma. 


\section{Use Mycosarcoma Bref. 1912 or Ustilago (Pers.) Roussel 1806 (S) rather than Pseudozyma Bandoni 1985 (A)}

The yeast-like morphs of Ustilaginales have been described in the genus Pseudozyma. Boekhout (1995) showed that the type species of Pseudozyma, P. prolifica, was closely related or synonymous wth Ustilago maydis, the cause of corn smut (Ainsworth 1965). While 26 names have been described in Pseudozyma, many of these have now been placed in diverse sexual genera such as Anthracocystis, Dirkmeia, Kalmanozyma, Langdonia, Moesziomyces and Sporisorium. A controversy exists over which generic name to use for the species long referred to as $U$. maydis, an earlier name for $P$. prolifica. The generic name Ustilago had been considered to be typified by $U$. hordei, cause of barley smut (Clinton 1906, Vánky 2012). This and related species, such as $U$. avenae, $U$. striiformis, and $U$. tritici were determined by McTaggart et al. (2016) to fall in a clade distinct from the one that included $U$. maydis, type of the resurrected generic name Mycosarcoma, which was based on morphological and cultural characteristics by Brefeld (1912). Based on molecular data, five names were included in Mycosarcoma by McTaggart et al. (2016), resurrecting Mycosarcoma maydis for the corn smut and closely related species. However, a proposal has been made to conserve the name Ustilago with $U$. maydis as the conserved type (Thines 2016). Pseudozyma prolifica is a name used for the asexual morph of Mycosarcoma / Ustilago maydis, thus we recommend the use of Mycosarcoma or Ustilago depending on whether the NCF votes to conserve the name Ustilago with a new type. Because the generic name Pseudozyma is no longer available, the taxonomic treatment of several names in Pseudozyma (e.g. P. alboarmeniaca, P. thailandica, $P$. tsukubaensis, $P$. pruni) is unclear as they cannot currently be placed with confidence in any sexually typified lineage (Wang et al. 2015a; these species are therefore temporarily retained in Pseudozyma "pro tem."

\section{Use Thecaphora Fingerh. 1836 (S) rather than Angiosorus Thirum. \& M.J. O'Brien 1974 (S), Rhombiella Liro 1939 (A) and Thecaphorella H. Scholz \& I. Scholz 1988 (A)}

The type species of Thecaphora, T. hyalina, is now regarded as T. seminis-convolvuli (Vánky et al. 2008). The type species of the asexually typified generic name Rhombiella, $R$. cardamines, is now regarded as Thecaphora thlaspeos (Vánky et al. 2008). The type of Thecaphorella, T. antherarum, was described as the asexual morph of Thecaphora seminisconvolvuli (Scholz \& Scholz 1988). Begerow et al. (1997) demonstrated that Thecaphora represents a well-resolved genus in Ustilaginales including the types of $T$. seminisconvolvuli and T. thlaspeos; these three generic names are therefore synonyms. Similarly, Andrade et al. (2004) and Vánky et al. (2008) demonstrated that Thecaphora includes $T$. seminis-convolvuli and T. solani (syn. Angiosorus solani, type of the monotypic generic name Angiosorus), an economically important fungus causing potato smut (Mordue 1988). Vánky (2012) includes over 60 species in Thecaphora, under which he lists four sexually typified generic names as later synonyms, along with the rejected name Sorosporium. Thecaphora has priority, includes numerous species, and is well known (GS The caphora $=1420$, Rhombiella $=5$, Angiosorus $=128$ ), thus we recommend the use of Thecaphora.

\section{Use Tilletia Tul. \& C. Tul. 1847 (S) rather than Tilletiella Zambett. 1970 (A)}

The genus Tilletia has long been accepted as the name for bunt fungi with over 100 accepted species, some of which cause serious diseases of crops in the grass family such as common bunt and dwarf bunt of wheat (Hoffman 1982, Mathre 1996). Tilletia, typified by T. caries, and treated as T. tritici, is now placed in Tilletiaceae (Tilletiales, Exobasidiomycetes; Begerow et al. 2006). The monotypic Tilletiella was established as an asexually typified genus for $T$. alopecuri, but that species is now regarded as Tilletia alopecuri (Vánky 2012). Tilletiella is therefore a synonym of Tilletia. Given the priority, large number of species, and widespread use (GS Tilletia $=16900$, Tilletiella $=0$ ), we recommend the use of Tilletia.

Use Urocystis Rabenh. ex Fuckel 1870, nom. cons. (S) rather than Paepalopsis J.G. Kühn 1882 (A)

The type species of Paepalopsis, P. irmischiae, is considered the asexual morph of Urocystis primulae, a species included in Urocystis, which is typified by U. occulta (Vánky 2012); these generic names are consequently synonyms. Vánky (2012) listed four sexually typified generic synonyms of Urocystis, including Tubercinia Fr. 1832 nom. sanct. and Polycystis Lév., earlier names of Urocystis which has been conserved over them (Wakefield 1939). Three names have been placed in Paepalopsis, two of which are now regarded as species of Urocystis, while the third, $P$. deformans, is now placed in the ascomycete genus Hapalosphaeria as $H$. deformans. Vánky (2012) accepted over 160 species of Urocystis in his world monograph of smut fungi. Given the priority, number of species, and widespread use (GS Urocystis $=4920$, Paepalopsis $=24$ ), Urocystis remains the correct name for this genus.

\section{ACKNOWLEDGEMENTS}

We are extremely grateful to the following individuals for their input, discussions, and suggestions: Gaddam Bagyanarayana, Cvetomir Denchev, David McLaughlin, Alistair McTaggart, Drew Minnis, Franz Oberwinkler (†), Angela Schäfer, Roger Shivas, John Wiersema, and Andrey Yurkov.

\section{REFERENCES}

Aime MC (2006) Toward resolving family-level relationships in rust fungi (Uredinales). Mycoscience 47: 112-122.

Aime MC, Matheny PB, Henk DA, Frieders EM, Nilsson RH, et al. (2006) An overview of the higher-level classification of Pucciniomycotina based on combined analyses of nuclear large and small subunit rDNA sequences. Mycologia 98: 896-905.

Ainsworth GC (1965) Ustilago maydis. Desciptions of Pathogenic Fungi and Bacteria 79: 1-2.

Alexopoulos CJ (1940) Some fungi from Greece. Mycologia 32: 336-358. 
Andrade O, Moñoz G, Galdames R, Durán P, Honorato R (2004) Characterization, in vitro culture, and molecular analysis of Thecaphora solani, the causal agent of potato smut. Phytopathology 94: 875-882.

Bandoni RJ, Boekhout T (1998) Agaricostilbum Wright. In: The Yeasts: a taxonomic study (Kurtzman CP, Fell JW, eds): 639640. $4^{\text {th }}$ edn. Amsterdam: Elsevier.

Bandoni R, Oberwinkler F (1981) Hyalopycnis blepharistoma: a pycnidial basidiomycete. Canadian Journal of Botany 59: 16131620.

Baral HO, Weber E, Gams W, Hagedorn G, Liu B et al. (2017) ["2018”] Generic names in the Orbiliaceae (Orbiliomycetes) and recommendations on which names should be protected or suppressed. Mycological Progress 17: 5-31.

Bauer R, Begerow D, Oberwinkler F, Marvanová L (2003) Classicula: the teleomorph of Naiadella fluitans. Mycologia 95: 756-764.

De Beer ZW, Seifert KA, Wingfield MJ (2013) A nomenclator for ophiostomatoid genera and species in the Ophiostomatales and Microascales. In: Ophiostomatoid Fungi: expanding frontiers (Seifert KA, De Beer ZW, Wungfiekld MJ, eds): 245-322. [CBS Biodiversity Series no. 12.] Utrecht: CBS-KNAW Fungal Biodiversity Centre.

Begerow D, Bauer R, Oberwinkler F (1997) Phylogenetic studies on nuclear LSU rDNA sequences of smut fungi and related taxa. Canadian Journal of Botany 75: 2045-2056.

Begerow D, John B, Oberwinkler F (2004). Evolutionary relationships among ß-tubulin gene sequences of basidiomycetous fungi. Mycological Research 108: 1257-1263.

Begerow D, Lutz M, Oberwinkler F (2002) Implications of molecular characters for the phylogeny of the genus Entyloma. Mycological Research 106: 1392-1399.

Begerow D, Stoll M, Bauer R (2006) A phylogenetic hypothesis of Ustilaginomycotina based on multiple gene analyses and morphological data. Mycologia 98: 906-916.

Berndt R (2015) The rust fungi (Uredinales) on ferns in South Africa. Mycological Progress 7: 7-19.

Boekhout T (1995) Pseudozyma Bandoni emend Boekhout, a genus for yeast-like anamorphs of Ustilaginales. Journal for General Applied Microbiology 41: 359-366.

Boerema GH, Loerakker WM, Hamers MEC (1987) Checklist for scientific names of common parasitic fungi. Supplement Series 2a (additions and corrections): Fungi on field crops: beet and potato; caraway, flax and oilseed poppy. Netherlands Journal of Plant Pathology 93 (Suppl.): 1-20.

Braun U (1995) A Monograph of Cercosporella, Ramularia and Allied Genera (Phytopathogenic Hyphomycetes). Vol. 1. Eching: IHWVerlag.

Braun U (2013) (2210-2232) Proposals to conserve the teleomorphtypified name Blumeria against the anamorph-typified name Oidium and twenty-two teleomorph-typified powdery mildew species names against competing anamorph-typified names (Ascomycota: Erysiphaceae). Taxon 62: 1328-1331.

Brefeld O (1812) Untersuchungen aus dem Gesammtgebiete der Mykologie. Vol. 15. Die Brandpilze und die Brandkrankheiten 5: 1-151. Münster: Commissions-Verlag v. H. Schöningh.

Castlebury LA, Carris LM, Vánky K (2005) Phylogenetic analysis of Tilletia and allied genera in order Tilletiales (Ustilaginomycetes; Exobasidiomycetidae) based on large subunit nuclear rDNA sequences. Mycologia 97: 888-900.

Clements FE, Shear CL (1931) The Genera of Fungi. New York, NY: H.W. Wilson Co.
Clinton GP (1906) Order Ustilaginales. North American Flora 7: 1-82. Cummins GB (1971) The Rust Fungi of Cereals, Grasses and Bamboos. New York: Springer-Verlag.

Cummins GB, Hiratsuka Y (2003) Illustrated Genera of Rust Fungi. $3^{\text {rd }}$ edn. St Paul, MN: American Phytopathological Society Press.

DanielH-M, Lachance M-A, Kurtzman CP (2014)Onthe reclassification of species assigned to Candida and other ascomycetous yeast genera based on phylogenetic circumscription. Antonie van Leeuwenhoek 10: 67-84.

De Carvalho AA, Hennen JF (2010) New species and nomenclature in Prospodium (Uropyxidaceae, Pucciniales) and the new anamorphic genus Canasta in the Neotropics. Mycologia 102: 1096-1113.

Demers JE, Liu M, Hambleton S, Castlebury LA (2017) Rust fungi on Panicum. Mycologia 109: 1-17.

Dietel P (1905) Uredinieae Japonicae. VI. Botanisches Jahrbücher 37: 97-109.

Donk MA (1962) The generic names proposed for Hymenomycetes. XII, Deuteromycetes. Taxon 11: 75-104.

Epstein L, Buurlage MB (1988) Nuclear division in germinating aeciospores and its taxonomic significance for the western gall rust fungus, Peridermium harknessii. Mycologia 80: 235-240.

Fell JW (1966) Sterigmatomyces, a new fungal genus from marine areas. Antonie van Leeuwenhoek 32: 99-104.

Fell JW, Statzell-Tallman A (1980) Mating between strains of the yeasts Aessosporon salmonicolor and Sporobolomyces spp. International Journal of Systematic Bacteriology 30: 206-207.

Gjaerum HB, Reid DA (1983) Three new species and a new combination in Uredinales. Transactions of the British Mycological Society 81: 650-654.

Hantula J, Kasanen R, Kaitera J, Moricca S (2002) Analysis of genetic variation suggest that pine rusts Cronartium flaccidum and Peridermium pini belong to the same species. Mycological Research 106: 203-209.

Hausner G, ReidJ, Eyjólfsdóttir GG, Iranpour M, Loewen P (2008) Basidiopycnides albertensis gen. et sp. nov., a new anamorphic fungus with phylogenetic affinities in the Atractiellales (Basidiomycota). Mycotaxon 103: 279-297.

Healy R, Pfister DH, Rossman AY, Marvanová L, Hansen K (2016) Competing sexual-asexual generic names of Pezizomycetes and recommendations for use. IMA Fungus 7: 285-288.

Hendrichs M, Begerow D, Bauer R, Oberwinkler F (2005) The genus Anthracoidea (Basidiomycota, Ustilaginales): a molecular phylogenetic approach using LSU rDNA sequences. Mycological Research 109: 31-40.

Henk DA, Vilgalys R (2007) Molecular phylogeny suggests a single origin of insect symbiosis in the Pucciniomycetes with support for some relationships within the genus Septobasidium. American Journal of Botany 94: 1515-1526.

Hernández JR, Hennen JF (2003) Rust fungi causing galls, witches' brooms, and other abnormal plant growths in northwestern Argentina. Mycologia 95: 728-755.

Hiratsuka N, Sato S, Katsuya K, Kakishima M, Hiratsuka Y, et al. (1992) The Rust Flora of Japan. Tsukuba: Tsukuba.

Hiratsuka Y (1969) Endocronartium, a new genus for autoecious pine stem rusts. Canadian Journal Botany 47: 1493-1495.

Hiratsuka $Y$ (1974) (373) Proposal to conserve the generic name Peridermium (Link) Schmidt \& Kunze with a conserved type secies, Aecidium elatinum Alb. \& Schw. (Fungi imperfecti uredinearum). Taxon 23: 428-429.

Hoffmann JA (1982) Bunt of wheat. Plant Disease 66: 979-986. 
Höhnel F (1916) Mykologisches. Österreich Botanische Zeitung 66 : 94-112.

Höhnel F (1924) Beitrag zur Kenntnis der Gattung Cylindrosporium Grev. Annales Mycologici 22: 191-203.

Hughes SL, Cavalcanti WA (1983) Janetia mangiferae n.sp. and the Johncouchia n. gen. anamorph of Septobasidium pilosum from Brasil. Canadian Journal of Botany 61: 2224-2230.

Imazu M, Azbukina ZM, Kakishima M, Fukushima K, Hishimura K, et al. (2000) Identification of a rust fungus on Pinus pumila collected in the North Kurils, Russia. Mycoscience 41: 139-144.

Imazu M, Kakishima M (1992) A new variety of Endocronartium sahoanum found on Pinus pumila in Hokkaido, Japan. Transactions of the Mycological Society of Japan 33: 167-176.

Imazu M, Kakishima M, Kaneko S (1989). Endocronartium sahoanum, a new stem rust fungus on Pinus pumila in Japan. Transactions of the Mycological Society of Japan 30: 301-310.

Jackson HS (1931) The rusts of South America based on the Holway collections -III. Mycologia 23: 96-116.

Johnston PR, Seifert KA, Stone JK, Rossman AY, Marvanová L (2014) Recommendations on generic names competing for use in Leotiomycetes (Ascomycota). IMA Fungus 5: 91-120.

Jørstad I (1934) A study on Kamtchatka Uredinales. Skrifter utgitt av Det Norske Videnskaps-Akademi I Oslo, nat.-naturv. klasse 1933(9): 1-183.

Kakishima M, Ji J-X, Wang Q, Li Y (2016) First report of rust disease caused by Milesina dryopteridis on two species of ferns, Rumohra adiantiformis and Pteris fauriei, in Japan. Plant Disease 100: 2529.

Kepler RM, Luangsa-ard JJ, Hywel-Jones NL, Quandt CA, Sung $\mathrm{G}-\mathrm{H}$, et al. (2017) A phylogenetic-based nomenclature for Cordycipitaceae (Hypocreales). IMA Fungus 8: 335-354.

Kern FD (1973) A Revised Taxonomic Account of Gymnosporangium. University Park, PN: Pennsylvania State University Press.

Kim MS, Klopfenstein NB, Ota Y, Lee SK, Woo KS, et al. (2010) White pine blister rust in Korea, Japan and other Asian regions: comparisons and implications for North America. Forest Pathology 40: 382-401.

Kirk PM, Cannon PF, Minter DW, Stalpers JA (2008) Ainsworth \& Bisby's Dictionary of the Fungi. $10^{\text {th }}$ edn. Wallingford: CAB International.

Kirschner R, Begerow D, Oberwinkler, F (2001) A new Chionosphaera species associated with conifer inhabiting bark beetles. Mycological Research 105: 1403-1408.

Kirschner R, Oberwinkler F (2009) Supplementary notes on Basidiopycnis hyalina (Basidiomycota, Atractiellales) and its anamorph. Mycotaxon 109: 29-38.

Klenke F, Scholler M (2015) Pflanzenparasitische Kleinpilze. Berlin: Springer.

Laundon GF (1965) The generic names of Uredinales. Mycological Papers 99: 1-24.

Laundon GF (1967) The taxonomy of the imperfect rusts. Transactions of the British Mycological Society 50: 349-353.

Laundon GF (1970) The lectotype of Uredo. Taxon 19: 947.

Liu XZ, Wang QM, Göker M, Groenwald M, Kachalkin AV et al. (2015) Towards an integrated phylogenetic classification of the Tremellomycetes. Studies in Mycology 81: 85-147.

Lutz M, Bauer R, Begerow D, Oberwinkler F (2004) TuberculinaThanatophytum/Rhizoctonia crocorum-Helicobasidium: a unique mycoparasitic-phytoparasitic life strategy. Mycological Research 108: 227-238.

Maier W, Begerow D, Weiss M, Oberwinkler F (2003) Phylogeny of the rust fungi: an approach using nuclear large subunit ribosomal
DNA sequences. Canadian Journal Botany 81: 12-23.

Marvanová L, Suberkropp K (1990) Camptobasidium hydrophilum and its anamorph, Crucella subtilis: a new heterobasidiomycete from streams. Mycologia 82: 208-217.

Mathre DE (1996) Dwarf bunt: politics, identification, and biology. Annual Review of Phytopathology 34: 67-86.

McNeill J, Barrie FF, Buck WR, Demoulin V, Greuter W, et al. (eds) (2012) International Code of Nomenclature for algae, fungi, and plants (Melbourne Code). [Regnum vegetabile no. 154.] Königstein: Koeltz Scientific Books.

McTaggart AR, Shivas RG, Boekhout T, Oberwinkler F, Vánky K et al. (2016). Mycosarcoma (Ustilaginaceae), a resurrected generic name for corn smut (Ustilago maydis) and its close relatives with hypertrophied, tubular sori. Journal of Plant Pathology 7 : 309-315.

Meinecke EP (1920) Facultative heteroecism in Peridermium cerebrum and Peridermium harknessii. Phytopathology 10: 279-297.

Mordue JEM (1988) Thecaphora solani. Descriptions of Pathogenic Fungi and Bacteria 966: 1-2.

Mordue JEM, Gibson IAS (1978) Cronartium flaccidum. Descriptions of Pathogenic Fungi and Bacteria 580: 1-2.

Oberwinkler F, Bandoni RJ (1982) A taxonomic survey of the gasteroid, auricularioid Heterobasidiomycetes. Canadian Journal of Botany 60: 1726-1750.

Oberwinkler F, Bauer R, Bandoni RJ (1990) Heterogastridiales: a new order of Basidiomycetes. Mycologia 82: 48-58.

Oberwinkler F, Kirschner R, Arenal F, Villarreal M, Ruio V, et al. (2006) Two new pycnidial members of the Atractiellales: Basidiopycnis hyalina and Proceropycnis pinicola. Mycologia 98: 637-649.

Ono Y (2015) Kuehneola species (Phragmidiaceae, Pucciniales) on Vitaceae plants. Mycological Progress 14: 50.

Ono Y, Kakishima M, Kudo A, Sato S (1986) Blastospora smilacis, a teleomorph of Caeoma makinoi, and its sorus development. Mycologia 78: 253-262.

Ono Y, Kakishima M, Sato S, Harada Y (1987) Blastospora itoana on Smilax nipponica forms a Caeoma stage on Prunus grayana in Japan. Mycologia 79: 668-673.

Petersen RH (1975) Report of the Special Committee for Fungi and Lichens. Taxon 24: 533-534.

Quandt CA, Kepler RM, Gams W, Araújo JPM, Ban S, et al. (2014) Phylogenetic-based nomenclatural proposals for Ophiocordycipitaceae (Hypocreales) with new combinations in Tolypocladium. IMA Fungus 5: 121-134.

Réblová M, Miller AN, Rossman AY, Seifert KA, Crous PW (2016) Recommendations for competing sexual-asexually typified generic names in Sordariomycetes (except Diaporthales, Hypocreales, and Magnaporthales). IMA Fungus 7: 131-153.

Ritz CM, Maier WF, Oberwinkler F, Wissemann V (2005) Different evolutionary histories of two Phragmidium species infecting the same dog rose hosts. Mycological Research 109: 603-609.

Roberts P (1999) Rhizoctonia-forming fungi: a taxonomic guide. Kew: Royal Botanic Gardens.

Rogers DP (1953) Disposition of nomina generica conservanda proposita for fungi. Mycologia 45: 312-322.

Rossman AY, Adams GC, Cannon PF, Castlebury LA, Crous PW, et al. (2015a) Recommendations of generic names in Diaporthales competing for protection or use. IMA Fungus 6: 145-154.

Rossman AY, Allen WC, Braun U, Castlebury LA, Crous PW, et al. (2016) Overlooked competing asexual and sexually typified generic names of Ascomycota with recommendations for their use or protection. IMA Fungus 7: 289-308. 
Rossman AY, Crous PW, Hyde KD, Hawksworth DL, Aptroot A, et al. (2015b) Recommended names of pleomorphic genera in Dothideomycetes. IMA Fungus 6: 507-523.

Rossman AY, Seifert KA, Samuels GJ, Minnis AM, Schroers H-J, et al. (2013) Genera in Bionectriaceae, Hypocreaceae, and Nectriaceae (Hypocreales) proposed for acceptance or rejection. IMA Fungus 4: 41-51.

Salazar-Yepes M, Carvalho jr AA, Hennen JF (2012) Blastospora in the Americas: a new combination and anamorphic genus and species. Mycologia 104: 115-120.

Salazar-Yepes M, Pardo Cardona VM, Buriticá Céspedes P (2007) Especies de Colombia, Ecuador y Perú pertenecientes al género Gerwasia Raciborski del Orden Uredinales. Caldasia 29: 105-120.

Sampaio JP (2011) Sporidiobolus Nyland (1949). In: The Yeasts: a taxonomic study (Kurtzman CP, Fell JW, Boekhout T, eds): 1549-1561. $5^{\text {th }}$ edn. Amsterdam: Elsevier.

Samson RA, Visagie CM, Houbraken J, Hong S-B, Hubka V, et al. (2014) Phylogeny, identification and nomenclature of the genus Aspergillus. Studies in Mycology 78: 141-173.

Sayama A, Kobayashi K, Ogoshi A (1994) Morphological and physiological comparisons of Helicobasidium mompa and $H$. purpureum. Mycoscience 35: 15-20.

Scholz H, Scholz I (1988) Taxonomische Erkenntnisse bei der Erarbeitung einer Brandpilzflora von Deutschland (Ustilaginales). Nova Hedwigia 47: 69-79.

Schumann G (1991) Plant Diseases: their biology and social impact. St Paul, MN: American Phytopathological Society Press.

Simpson JA, Thomas K, Grgurinovic CA (2006) Uredinales species pathogenic on species of Myrtaceae. Australasian Plant Pathology 35: 549-562.

Smith PA (2015) Rust fungi on ferns. Field Mycology 16: 49-53.

Stadler M, Kuhnert E, Peršoh D, Fournier J (2013) The Xylariaceae as model example for a unified nomenclature following the "One fungus-one name" (1F1N) concept. Mycology 4: 5-21.

Statzell-Tallman A, Fell J (1998) 105-Rhodotorula. In: The Yeasts: a taxonomic study (Kurtzman CP, Fell JW, eds): 800-827. $4^{\text {th }}$ edn. Amsterdam: Elsevier.

Tanase C, Negrean G (2007) The genus Milesina Magnus (Fungi, Basidiomycota) in Romania. Analele Stiintifice ale Universitatii "Al. I. Cuza" din lasi, Biologie Vegetala, ser. nov.,. Sect. II A 53: 108-113.

Thines M (2016) (2467) Proposal to conserve the name Ustilago (Basidiomycota) with a conserved type. Taxon 65: 1170-1171.

Thirumalachar MJ, Kern FD, Patil BV (1966) Elateraecium, a new form genus of Uredinales. Mycologia 58: 391-396.

Thirumalachar MJ, Kern FD, Patil BV (1975) Hiratsukamyces, a new genus of the Pucciniastreae. Sydowia 27: 78-81.

Toome M, Aime MC (2014) Pycnopulvinus aurantiacus, gen. \& sp. nov., a new sporocarp-forming member of the Pucciniomycotina from Ecuador. MycoKeys 8: 43-50.

Toome M, Pennycook SR, Aime MC (2015) The generic names Kriegeria. Mycotaxon 130: 321-328.

Turland NJ, Wiersema JH, Barrie FR, Greuter W, Hawksworth DL, et al. (eds) (2018) International Code of Nomenclature for algae, fungi, and plants (Shenzhen Code) adopted by the Nineteenth International Botanical Congress Shenzhen, China, July 2017. [Regnum Vegetabile no. 159.] Königstein: Koeltz Botanical Books.
Turland NJ, Wiersema JH, Munro AM, Deng Y-F, Zhang L (2017) XIX International Botanical Congress: report of Congress action on nomenclature proposals. Taxon 66: 1234-1245.

Van der Walt JP (1970) The perfect and imperfect states of Sporobolomyces salmonicolor. Antonie van Leeuwenhoek 36: 49-55.

Van der Walt JP (1973) Aessosporon dendrophilum sp. nov., the perfect state of Bullera dendrophila. Antonie van Leeuwenhoek 39: 455-460.

Vánky K (2012) Smut Fungi of the World. St Paul, MN: American Phytopathological Society Press.

Vánky, K, Lutz M, Bauer R (2008) About the genus Thecaphora (Glomosporiaceae) and its new synonyms. Mycological Progress 7: 31-39.

Visagie CM, Houbraken J, Frisvad JC, Hong S-B, Klaassen CHW, et al. (2014) Identification and nomenclature of the genus Penicillium. Studies in Mycology 78: 343-371.

Vogler DR, Bruns TD (1998) Phylogenetic relationships among the pine stem rust fungi (Cronartium and Peridermium spp.). Mycologia 90: 244-257.

Wakefied E (1939) Nomina generica conservanda: Contributions from the nomenclature committee of the British Mycological Society. I. Transactions of the British Mycological Society 23: 215-232.

Wang Q-M, Yurkov AM, Göker M, Lumbsch HT, Leavit SD, et al. (2015a) Phylogenetic classification of yeasts and related taxa within Pucciniomycotina. Studies in Mycology 81: 149-189.

Wang Q-M, Begerow D, Groenewald M et al. (2015b) Multigene phylogeny and taxonomic revision of yeasts and related fungi in the Ustilaginomycotina. Studies in Mycology 81: 27-53.

Wijayawardene DNN, McKenzie EHC, Hyde KD (2012) Towards incorporating anamorphic fungi in a natural classification checklist and notes for 2011. Mycosphere 3: 157-228.

Wingfield BD, Ericson L, Szaro T, Burdon JJ (2004) Phylogenetic patterns in the Uredinales. Australasian Plant Pathology 33: 327-335.

Wright JE (1970) Agaricostilbum, a new genus of Deuteromycetes on palm spathes from Argentina. Mycologia 62: 679-682.

Wright JE, Bandoni R, Oberwinkler F (1981) Agaricostilbum: an auricularioid basidiomycete. Mycologia 73: 880-886.

Yun HY, Hong SG, Rossman AY, Lee SK, Lee KJ, et al. (2009) The rust fungus Gymnosporangium in Korea including two new species, G. monticola and G. unicorne. Mycologia 101: 790-809.

Yun H-Y, Minnis AM, Kim Y-H, Castlebury LA, Aime MC (2011) The rust genus Frommeëlla revisited: a later synonym of Phragmidium afterall. Mycologia 103: 1451-1463.

Zhang N, Luo J, Rossman A, Aoki T, Chuma I, et al. (2016) Generic names in Magnaporthales. IMA Fungus 7: 155-159. 